\title{
Sub-therapeutic Drug Level
}

National Cancer Institute

\section{Source}

National Cancer Institute. Sub-therapeutic Drug Level. NCI Thesaurus. Code C102715.

A drug serum concentration below therapeutic levels. 